Ekonomis: Journal of Economics and Business, 5(1), Maret 2021, 303-313

Publisher: Lembaga Penelitian dan Pengabdian kepada Masyarakat Universitas Batanghari Jambi

Address: Jl. Slamet Ryadi, Broni-Jambi Kodepos: 36122

Website: http://ekonomis.unbari.ac.id, email: ekonomis.unbari@gmail.com

ISSN 2597-8829 (Online), DOI 10.33087/ekonomis.v5i1.326

\title{
Pengaruh Sistem Administrasi Modern, Keadilan, Akuntabilitas, Dan Sanksi Perpajakan terhadap Kepatuhan Wajib Pajak UMKM Kota Jambi
}

\author{
Eva Setiarini Damanik \\ Sekolah Tinggi Ilmu Graha Karya Muara Bulian \\ Correspondence email: setia_superior@yahoo.com
}

\begin{abstract}
Abstrak. Penelitian ini bertujuan untuk menguji pengaruh sistem administrasi modern, keadilan, akuntabilitas, dan sanksi perpajakan terhadap kepatuhan wajib pajak UMKM Kota Jambi. Penelitian ini menggunakan metode simple random sampling dengan 100 responden wajib pajak UMKM di Kota Jambi. Teknik pengumpulan data dalam penelitian ini adalah dalam bentuk kuesioner. Analisis yang digunakan adalah analisis regresi linear berganda dengan menggunakan IBM SPSS (Statistical Package for Social Sciense) versi 21. Hasil penelitian ini menunjukkan bahwa variabel sistem administrasi modern, keadilan, akuntabilitas, dan sanksi perpajakan berpengaruh terhadap kepatuhan wajib pajak UMKM.
\end{abstract}

Kata Kunci: Sistem Administrasi Modern; Keadilan; Akuntabilitas; dan Sanksi Perpajakan

Abstract. This study aims to examine the effect of the modern administration system, justice, accountability, and tax sanctions on the tax compliance of the MSMEs of the City of Jambi. This study uses a simple random sampling method with 100 UMKM taxpayer respondents in the city of Jambi. Data collection techniques in this study were in the form of questionnaires. The analysis used is multiple linear regression analysis using IBM SPSS (Statistical Package for Social Sciences) version 21. The results of this study indicate that the variables of modern administrative systems, justice, accountability, and tax sanctions affect the compliance of MSME taxpayers.

Keywords: Modern Administrative Systems; Justice; Accountability and Tax Sanctions

\section{PENDAHULUAN}

Pajak merupakan pungutan yang dilakukan secara resmi oleh Pemerintah kepada rakyatnya yang dilindungi oleh Undang - Undang yang dibuat oleh Pemerintah sendiri. Pajak dapat dikelompokkan menjadi 2 (dua), yaitu pajak tahun berjalan yang bersumber dari dalam dan luar negeri serta pajak yang berasal dari tuntutan Pemerintah kepada wajib pajak yang berada di Peradilan pajak (Pandiangan, 2015). Kepatuhan wajib pajak yaitu dimana wajib pajak memenuhi kewajiban perpajakannya dan melaksanakan hak perpajakan dengan baik dan benar sesuai dengan peraturan dan undang-undang pajak yang berlaku (Danarsi, dkk., 2017). Sistem administrasi perpajakan modern merupakan sistem administrasi perpajakan yang mengalami penyempurnaan agar lebih efisien, ekonomis dan cepat yang digagas oleh ditjen pajak. Direktorat Jenderal Pajak melaksanakan sistem administrasi modern dengan memberikan pelayanan berbasis e-system seperti e-SPT, e-filing, e-payment, dan e-registration untuk mendukung transparansi dan keterbukaan serta mengantisipasi terjadinya korupsi, kolusi dan nepotisme serta penyalahgunaan kekuasaan dan wewenang (Sarunan, 2015). Keadilan pajak adalah sifat (perbuatan atau perlakuan) yang tidak sewenang- wenang atau tidak berat sebelah atas sistem perpajakan yang berlaku. Dapat disimpulkan bahwa keadilan perpajakan adalah penyetaraan terhadap kebijakan dalam sistem perpajakan sesuai dengan keadaan wajib pajak yang sebenarnya (Mustofa, dkk., 2016).Akuntabilitas merupakan hubungan antara pihak yang memiliki kekuatan formal atas pihak pengendali dengan pihak yang berkuasa. Tujuan akhir dari akuntabilitas pemerintah adalah untuk memastikan uang pajak yang dibayarkan dikelola dan dimanfaatkan secara efisien dan efektif untuk kepentingan masyarakat (Putri, dkk., 2019) . Sanksi perpajakan merupakan jaminan bahwa ketentuan peraturan perundangundangan perpajakan (norma perpajakan) akan dituruti/ditaati/dipatuhi (Mardiasmo, 2016).

Penelitian ini merupakan pengembangan dari penelitian yang dilakukan (Putri, dkk., 2019) "Pengaruh Sistem Administrasi Perpajakan Modern, Akuntabilitas Dan Sanksi Perpajakan Terhadap Kepatuhan Wajib Pajak"

Perbedaan pada penelitian ini yaitu:

1. Menambahkan variabel keadilan.

2. Objek pada penelitian ini adalah Wajib Pajak UMKM yang terdaftar di Dinas Koperasi, UKM, Tenaga Kerja, dan Transmigrasi Kota Jambi. Sedangkan objek dari penelitian (Putri, dkk., 2019) adalah UMKM yang terdaftar di KPP Pratama Jambi. 
Terdapat beberapa penelitian terdahulu yang ditemukan terjadi inkonsisten hasil pada variabel sistem administrasi modern, akuntabilitas, sanksi perpajakan. Pada penelitian Putri, dkk., (2019), Aryati dan Putritanti (2016), Prabawati (2017), Sarunan (2015) sistem administrasi modern berpengaruh terhadap kepatuhan wajib pajak UMKM . Sedangkan pada penelitian Qodariyah, dkk., (2018) dan Putra (2017) sistem administrasi modern tidak berpengaruh terhadap kepatuhan wajib pajak kendaraan UMKM.

Pada penelitian Putri, dkk., (2019) dan Broto (2018) akuntabilitas berpengaruh terhadap kepatuhan wajib pajak UMKM. Sedangkan pada penelitian Lilisen, dkk., (2018) akuntabilitas tidak berpengaruh terhadap kepatuhan wajib pajak UMKM.

Pada penelitian Putri, dkk (2019), Ngadiman dan Huslin (2015) sanksi perpajakan berpengaruh terhadap kepatuhan wajib pajak UMKM. Sedangkan pada penelitian Ermawati \& Afifi (2018) sanksi perpajakan tidak berpenaruh terhadap kepatuhan wajib pajak UMKM.

Dari uraian diatas, penulis tertarik untuk menguji ulang tentang pengaruh sistem administrasi modern, akuntabilitas, dan sanksi perpajakan terhadap kepatuhan wajib pajak UMKM. Penulis juga menambahkan variabel penerapan keadilan pada penelitian ini.

\section{Tinjauan Pustaka}

Pajak merupakan pungutan wajib yang dipungut secara teratur dan dilindungi peraturan (misalnya undangundang) oleh pemegang otoritas keuangan dalam satu wilayah dalam jangka waktu tertentu dan penggunaannya dikendalikan oleh otoritas kekuasaan tanpa membuat pertanggungjawaban secara langsung kepada pemberi pajak (Pandiangan, 2015).

\section{Usaha Mikro, Kecil, dan Menengah}

Sesuai dengan Undang-Undang Nomor 20 Tahun 2008 tentang Usaha Mikro, Kecil dan Menengah (UMKM), pengertian Usaha Mikro, Kecil dan Menengah adalah sebagai berikut: Usaha Mikro adalah usaha produktif milik orang perorangan dan/atau badan usaha perorangan yang memenuhi kriteria Usaha Mikro sebagaimana diatur dalam Undang-Undang. Usaha Kecil adalah usaha ekonomi produktif yang berdiri sendiri, yang dilakukan oleh orang perorangan atau badan usaha yang bukan merupakan anak perusahaan atau bukan cabang perusahaan yang dimiliki, dikuasai, atau menjadi bagian baik langsung maupun tidak langsung dari usaha menengah atau usaha besar yang memenuhi kriteria Usaha Kecil sebagaimana dimaksud dalam Undang-Undang. Usaha Menengah adalah usaha ekonomi produktif yang berdiri sendiri, yang dilakukan oleh orang perseorangan atau badan usaha yang bukan merupakan anak perusahaan atau cabang perusahaan yang dimiliki, dikuasai, atau menjadi bagian baik langsung maupun tidak langsung dengan Usaha Kecil atau usaha besar dengan jumlah kekayaan bersih atau hasil penjualan tahunan sebagaimana diatur dalam Undang-Undang. Adapun kriteria usaha mikro, kecil dan menengah adalah sebagai berikut:

Tabel 1

Kriteria UMKM

\begin{tabular}{llll}
\hline No & \multicolumn{1}{c}{ Uraian Asset } & & Omset \\
\hline 1 & Usaha Mikro & Maks. 50 juta & Maks. 300 Juta \\
2 & Usaha Kecil & $>50$ Juta -500 juta & $>300$ Juta $-2,5$ Miliar \\
3 & Usaha Menengah & $>500$ Juta -1 Milyar & $>2,5$ Miliar -50 Miliar \\
\hline
\end{tabular}

sumber: www.depkop.go.id dalam Tatik (2018)

Tabel di atas menjelaskan kriteria UMKM berdasarkan asset dan omset pertahun, bahwa Usaha Mikro adalah usaha yang memiliki asset maksimal Rp 50.000.000,00 dan omset maksimal Rp 300.000.000,00. Usaha Kecil memiliki asset lebih dari Rp 50.000.000,00 sampai dengan $\mathrm{Rp} 500.000 .000,00$ dan omset lebih dari $\mathrm{Rp}$ 300.000.000,00 sampai dengan Rp 2.500.000.000,00. Sedangkan Usaha Menengah memiliki asset lebih dari Rp 500.000.000,00 sampai dengan Rp 10.000.000.000 dan omset lebih dari Rp 2.500.000.000,00 sampai dengan Rp50.000.000.000,00.

\section{Wajib Pajak}

Menurut Undang-Undang No. 16 Tahun 2009 tentang Perubahan Ketiga atas Undang-Undang No. 6 Tahun 1983 tentang ketentuan Perpajakan adalah "Wajib Pajak adalah orang pribadi atau badan, meliputi pembayar pajak dan pemungut pajak yang mempunyai hak dan kewajiban perpajakan sesuai dengan ketentuan peraturan perundangundangan perpajakan". 
Menurut Mardiasmo (2016), Wajib Pajak adalah orang pribadi atau badan, meliputi pembayar pajak, pemotong pajak dan pemungut pajak yang mempunyai hak dan kewajiban perpajakan sesuai dengan ketentuan peraturan perundang-undangan perpajakan.

\section{Kepatuhan Wajib Pajak}

Kepatuhan wajib pajak adalah sikap wajib pajak yang berusaha untuk mematuhi segala peraturan perpajakan dengan tanpa dipaksa (Subekti, 2016). Sedangkan menurut Sufiah dan Lintang (2017) kepatuhan wajib pajak merupakan sikap wajib pajak dalam memenuhi kewajiban perpajakannya, yaitu wajib membayar pajak tepat waktu dan wajib melaporkan pajak tepat waktu. Menurut Rahayu (2017), Kriteria wajib pajak yang patuh sebagai berikut 1). Tepat waktu dalam penyampaian Surat Pemberitahuan (SPT), 2). Tidak memiliki tunggakan pajak, 3). Tidak pernah dipidana terkait pelanggaran pajak.

Kepatuhan wajib pajak merupakan pemenuhan kewajiban perpajakan yang dilakukan oleh pembayar pajak dalam rangka memberikan kontribusi bagi pembangunan dewasa ini yang diharapkan di dalam pemenuhannya diberikan secara sukarela. Kepatuhan wajib pajak menjadi aspek penting mengingat sistem perpajakan Indonesia menganut sistem Self Asessment di mana dalam prosesnya secara mutlak memberikan kepercayaan kepada wajib pajak untuk menghitung, membayar dan melapor kewajibannya (bppk.kemenkeu.go.id)

Menurut Keputusan Menteri Keuangan No. 544/KMK.04/2000, kepatuhan wajib pajak dapat diidentifikasi dari:

a. Tepat waktu dalam menyampaikan SPT untuk semua jenis pajak dalam dua tahun terakhir.

b. Tidak mempunyai tunggakan pajak untuk semua jenis pajak, kecuali telah memperoleh izin untuk mengangsur atau menunda pembayaran pajak.

c. Tidak pernah dijatuhi hukuman karena melakukan tindak pidana di bidang perpajakan dalam jangka waktu 10 tahun terakhir.

d. Dalam 2 tahun terakhir menyelenggarakan pembukuan dan dalam hal terhadap wajib pajak pernah dilakukan pemeriksaan, koreksi pada pemeriksaan yang terakhir untuk masing-masing jenis pajak yang terutang paling banyak $5 \%$.

e. Wajib pajak yang laporan keuangannya untuk 2 tahun terakhir diaudit oleh akuntan publik dengan pendapat wajar tanpa pengecualian, atau pendapat dengan pengecualian sepanjang tidak mempengaruhi laba rugi fiskal.

\section{METODE}

Penelitian ini disusun dengan menggunakan beberapa variabel antara lain Sistem Administrasi Modern, Keadilan, Akuntabilitas, Sanksi Perpajakan dan Kepatuhan Wajib Pajak UMKM Kota Jambi.

Data penelitian ini menggunakan data primer. Data primer mengacu pada informasi yang diperoleh langsung (dari tangan pertama) oleh peneliti terkait dengan variabel ketertarikan untuk tujuan tertentu dari studi (Sekaran \& Bougie, 2017). Data penelitian ini diperoleh dari penyebaran kuesioner kepada wajib pajak UMKM Kota Jambi. Kuesioner merupakan teknik pengumpulan data yang dilakukan dengan cara memberi seperangkat pertanyaan atau pernyataan tertulis kepada responden untuk dijawabnya (Sugiyono, 2016).

Jenis penelitian yang digunakan dalam penelitian ini adalah penelitian kuantitatif. Metode penelitian kuantitatif adalah metode penelitian yang berlandaskan pada filsafat positivism, digunakan untuk meneliti pada populasi atau sampel tertentu, pengumpulan data menggunakan instrument penelitian, analisis data bersifat kuantitatif/statistik dengan tujuan untuk menguji hipotesis yang telah ditetapkan (Sugiyono, 2016).

\section{Populasi dan Sampel Penelitian}

Populasi adalah wilayah generalisasi yang terdiri atas objek atau subjek yang mempunyai kualitas dan karakteristik tertentu yang ditetapkan oleh peneliti untuk dipelajari dan kemudian ditarik kesimpulannya (Sugiyono, 2016). Populasi dalam penelitian ini adalah UMKM yang terdaftar di Dinas Koperasi, UKM, Tenaga Kerja, dan Transmigrasi Kota Jambi yang berjumlah 23.000.

Sampel adalah bagian dari jumlah dan karakteristik yang dimiliki oleh populasi tersebut. Pengukuran sampel merupakan suatu langkah untuk menentukan besarnya sampel yang diambil dalam melaksanakan penelitian suatu objek (Sugiyono, 2016). Pengambilan sampel dalam penelitian ini dilakukan dengan teknik Simple Random sampling. Simple Random Sampling adalah pengambilan anggota sampel dari populasi yang dilakukan secara acak tanpa memperhatikan strata yang ada dalam populasi itu (Sugiyono, 2016).

Sampel pada penelitian ini kemudian dihitung dengan rumus slovin:

$$
n=\frac{N}{1+N(e)^{2}}
$$


Eva Setiarini Damanik, Pengaruh Sistem Administrasi Modern, Keadilan, Akuntabilitas, Dan Sanksi Perpajakan terhadap Kepatuhan Wajib Pajak UMKM Kota Jambi

Keterangan :

$\begin{array}{ll}\mathrm{n} & =\text { jumlah sampel } \\ \mathrm{N} & =\text { ukuran populasi } \\ \mathrm{e} & =\text { prosentase kelonggaran ketelitian kesalahan pengambilan sampel yang masih bisa ditoleransi, } \\ \mathrm{e} & =0,1\end{array}$

Rentang sampel yang dapat diambil dari rumus slovin adalah 10\%. Dengan jumlah 23.000 UMKM Kota Jambi dan prosentase kelonggaran ketelitian 10\%, ukuran sampel dalam penelitian ini adalah :

$n=\frac{23.000}{1+23.000(e)^{2}}$

$n=\frac{23.000}{1+23.000(0,1)^{2}}$

$n=\frac{23.000}{1+231}$

$n=\frac{23.000}{232}$

$n=99,56=$ dibulatkan menjadi 100

\section{HASIL DAN PEMBAHASAN}

Hasil Analisis Data

Uji Statistik Deskriptif

Menurut Ghozali (2018) statistik deskriptif memberikan gambaran atau deskripsi suatu data yang dilihat dari nilai rata-rata (mean), standar deviasi, varian, maksimum, minimum, sum, range, kurtosis dan skewness (kemencengan distribusi). Dalam penelitian ini hanya menggunakan nilai rata-rata (mean), standar deviasi, maksimum, dan minimum. Variabel-variabel yang digunakan dalam penelitian ini adalah Sistem Administrasi Modern, Keadilan, Akuntabilitas, Dan Sanksi Perpajakan terhadap Kepatuhan Wajib Pajak UMKM Di Kota Jambi. Pada tabel berikut dapat dilihat hasil analisis statistik deskriptif variabel-variabel yang digunakan dalam penelitian ini.

Tabel 2

Statistik Deskriptif Variabel Penelitian

Descriptive Statistics

\begin{tabular}{|c|c|c|c|c|c|}
\hline & $\mathrm{N}$ & Minimum & Maximu $\mathrm{m}$ & Mean & $\begin{array}{c}\text { Std. } \\
\text { Deviation }\end{array}$ \\
\hline RATARATA_X1 & 100 & 1,43 & 5,00 & 4,0727 &, 74454 \\
RATARATA_X2 & 100 & 1,75 & 5,00 & 3,7900 &, 70058 \\
RATARATA_X3 & 100 & 1,00 & 5,00 & 3,3175 &, 76859 \\
RATARATA_X4 & 100 & 2,63 & 5,00 & 4,0048 &, 50667 \\
RATARATA_Y & 100 & 2,22 & 5,00 & 4,1342 &, 53015 \\
Valid N (listwise) & 100 & & & & \\
\hline
\end{tabular}

Sumber: Data Olahan Output IBM SPSS versi 21 (2020).

\section{Uji Instrumen \\ Uji Validitas}

Validitas menguji seberapa baik suatu instrumen dibuat untuk mengukur konsep tertentu yang ingin diukur (Sekaran dan Bougie, 2017). Uji validitas digunakan untuk mengukur sah atau valid tidaknya suatu kuesioner. Valid berarti instrumen tersebut dapat digunakan untuk mengukur apa yang seharusnya diukur. Suatu kuesioner dikatakan valid jika pertanyaan atau pernyataan pada kuesioner mampu mengungkapkan sesuatu yang akan diukur oleh kuesioner tersebut, dan suatu variabel dikatakan valid apabila nilai signifikansi lebih kecil dari 0,05 (Ghozali, 2018). Berikut ini adalah tabel yang menunjukkan hasil validitas keempat variabel dengan 100 responden:

\section{Uji Reliabilitas}

Menurut Ghozali (2018), reliabilitas adalah alat untuk mengukur suatu kuesioner yang merupakan indikator dari variabel atau konstruk. Suatu kuesioner dikatakan reliabel atau handal jika jawaban seseorang terhadap pernyataan 
Eva Setiarini Damanik, Pengaruh Sistem Administrasi Modern, Keadilan, Akuntabilitas, Dan Sanksi Perpajakan terhadap Kepatuhan Wajib Pajak UMKM Kota Jambi

adalah konsisten atau stabil dari waktu ke waktu. Menurut Ghozali (2018), suatu konstruk atau variabel dikatakan reliabel jika memberikan nilai Cronbach Alpha > 0,7.

Tabel 3

Hasil Uji Realibilitas

\begin{tabular}{|l|l|l|}
\hline Variabel & Cronbach`s Alpha & Keterangan \\
\hline Sistem Administrasi Modern & .928 & Reliabel \\
\hline Keadilan & .726 & Reliabel \\
\hline Akuntabilitas & .761 & Reliabel \\
\hline Sanksi Perpajakan & .776 & Reliabel \\
\hline Kepatuhan Wajib Pajak UMKM Kota Yogyakarta & .859 & Reliabel \\
\hline
\end{tabular}

Sumber: Data Olahan Output IBM SPSS versi 21 (2020)

Berdasarkan uji realibilitas dalam tabel diatas dapat diketahui bahwa Cronbach`s Alpha pada masing-masing variabel lebih besar dari 0,7 . Hal tersebut menunjukkan bahwa seluruh variabel penelitian dapat dinyatakan reliabel. Sehingga butir-butir pernyataan dalam variabel dapat digunakan untuk penelitian selanjutnya.

\section{Uji Asumsi Klasik \\ Uji Normalitas}

Uji normalitas dilakukan untuk menguji model regresi apakah variabel residual memiliki distribusi yang normal. Pengujian ini menggunakan uji normalitas dari Kolmogorov-Smirnov dengan pengambilan keputusan jika nilai probabilitas >0,05 maka model regresi memenuhi asumsi normalitas (Ghozali, 2018).

Tabel 4

Uji Normalitas

\begin{tabular}{|c|c|c|}
\hline \multicolumn{3}{|c|}{ One-Sample Kolmogorov-Smirnov Test } \\
\hline & & Unstandardiz ed Residual \\
\hline \multicolumn{2}{|l|}{$\mathrm{N}$} & 100 \\
\hline \multirow[b]{2}{*}{ Normal Parameters ${ }^{\mathrm{a}, \mathrm{b}}$} & Mean & .0000000 \\
\hline & Std. Deviation & 3.84167301 \\
\hline \multirow[t]{3}{*}{ Most Extreme Differences } & Absolute & .049 \\
\hline & Positive & .049 \\
\hline & Negative & -.040 \\
\hline \multicolumn{2}{|l|}{ Kolmogorov-Smirnov Z } & .492 \\
\hline \multicolumn{2}{|l|}{ Asymp. Sig. (2-tailed) } & .969 \\
\hline \multicolumn{3}{|l|}{ a. Test distribution is Normal. } \\
\hline \multicolumn{3}{|l|}{ b. Calculated from data. } \\
\hline
\end{tabular}

Sumber: Data Olahan Output IBM SPSS versi 21 (2020)

Berdasarkan Tabel 4 dengan menggunakan uji kolmogorov-smirnov maka dapat disimpulkan bahwa data terdistribusi secara normal karena nilai asymp. Sig. (2- tailed) sebesar 0,969. Jika nilai asymp. Sig. (2-tailed) lebih besar dari 0,05 maka data terdistribusi secara normal.

\section{Uji Heterokedastisitas}

Uji Heterokedastisitas bertujuan untuk menguji apakah dalam model regresi terjadi ketidaksamaan varian dari residual satu ke pengamatan yang lain (Ghozali, 2018). Model regresi yang memenuhi persyaratan adalah jika terdapat kesamaan varian residual satu pengamatan ke pengamatan lain tetap atau disebut homokedastisitas. Adapun hasil pengujian heterokedastisitas ditunjukan tabel berikut ini:

Tabel 5

Hasil Uji Heterokedastisitas

\begin{tabular}{|c|c|c|c|c|c|c|}
\hline \multicolumn{7}{|c|}{ Coefficientsa } \\
\hline \multirow{2}{*}{\multicolumn{2}{|c|}{ Model }} & \multicolumn{2}{|c|}{ Unstandardized Coefficients } & \multirow{2}{*}{$\begin{array}{c}\text { Standardized Coefficient S } \\
\text { Beta }\end{array}$} & \multirow[t]{2}{*}{$\mathrm{t}$} & \multirow[t]{2}{*}{ Sig. } \\
\hline & & $\mathrm{B}$ & Std. Error & & & \\
\hline \multirow{5}{*}{1} & (Constant) & 10.139 & 9.503 & & 1.067 & .289 \\
\hline & Sistem Administrasi Modern & .150 & .200 & .079 & .748 & .456 \\
\hline & Keadilan & .048 & .393 & .014 & .123 & .902 \\
\hline & Akuntabilitas & .152 & .376 & .047 & .404 & .687 \\
\hline & Sanksi Perpajakan & -.407 & .270 & -.166 & -1.507 & .135 \\
\hline
\end{tabular}


Eva Setiarini Damanik, Pengaruh Sistem Administrasi Modern, Keadilan, Akuntabilitas, Dan Sanksi Perpajakan terhadap Kepatuhan Wajib Pajak UMKM Kota Jambi

a. Dependent Variable: ABS_RES

Sumber: Data Olahan Output IBM SPSS versi 21 (2020)

Tabel 5 merupakan hasil uji heterokedastisitas yang dilakukan dengan uji glejser. Dilihat dari nilai signifikansi diatas 0,05 dari setiap variabel independen, dapat dikatakan bahwa model regresi berganda dalam penelitian tidak terjadi heterokedastisitas.

\section{Uji Multikolinieritas}

Ghozali (2018) mengemukakan, uji multikolonieritas digunakan untuk menguji apakah model regresi linier berganda ditemukan adanya korelasi antar variabel bebas (independen). Apabila terdapat korelasi yang tinggi diantara variabel bebasnya, maka hubungan antar variabel bebas dengan variabel terikat akan terganggu. Pengujian multikolonieritas dapat dilakukan dengan menganalisis korelasi antar variabel dilihat dari perhitungan nilai tolerance dan Variance Infitaion Vactor (VIF). Multikolonieritas terjadi apabila nilai tolerance $>0,1$ yang berarti tidak ada korelasi antar variabel independen yang nilainya lebih dari 95\% dan nilai VIF < 10. Apabila nilai VIF < 10 dapat dikatakan bahwa variabel yang digunakan dalam model penelitian dapat dipercaya dan obyektif. Hasil uji multikolonieritas dapat dilihat ditabel berikut:

Tabel 6

Hasil Uji Multikolonieritas

\begin{tabular}{|c|c|c|c|c|c|c|c|c|}
\hline \multicolumn{9}{|c|}{ Coefficients $^{\mathrm{a}}$} \\
\hline \multirow{2}{*}{\multicolumn{2}{|c|}{ Model }} & \multicolumn{2}{|c|}{$\begin{array}{l}\text { Unstandardized } \\
\text { Coefficients }\end{array}$} & \multirow{2}{*}{\begin{tabular}{|l} 
Standardized \\
Coefficients
\end{tabular}} & \multirow[t]{2}{*}{$T$} & \multirow[t]{2}{*}{ Sig. } & \multicolumn{2}{|c|}{ Collinearity Statistics } \\
\hline & & $\mathrm{B}$ & Std. Error & & & & Toleran ce & VIF \\
\hline \multirow[b]{5}{*}{1} & (Constant) & 12.194 & 3.729 & & 3.270 & .001 & & \\
\hline & Sistem Administrasi Modern & .162 & .078 & .177 & 2.062 & .042 & .928 & 1.078 \\
\hline & Keadilan & .326 & .154 & .191 & 2.113 & .037 & .833 & 1.200 \\
\hline & Akuntabilitas & .329 & .148 & .212 & 2.226 & .028 & .754 & 1.326 \\
\hline & Sanksi Perpajakan & .347 & .106 & .295 & 3.274 & .001 & .843 & 1.187 \\
\hline
\end{tabular}

a. Dependent Variable: Kepatuhan Wajib Pajak

Sumber: Data Olahan Output IBM SPSS versi 21 (2020)

Dari Tabel 6 dapat diketahui bahwa semua variabel independen memiliki nilai tolerance $>0,1$ dan nilai VIF < 10. Dengan demikian dapat disimpulkan bahwa persamaan model regresi tidak ada masalah multikolonieritas, yang dapat diartikan tidak terdapat hubungan antar variabel independen sehingga layak digunakan dalam penelitian lebih lanjut.

\section{Analisis Regresi Linear Berganda}

Alat analisis penelitian ini adalah regresi linear berganda. Analisis regresi linear berganda adalah untuk mengetahui hubungan antar variabel terikat dengan variabel bebas (Ghozali, 2018). Berdasarkan pada pengolahan data menggunakan software SPSS versi 21 sehingga dapat diperoleh suatu model regresi linier berganda sebagai berikut:

Tabel 7

Hasil Analisis Regresi Linier Berganda Coefficientsa

\begin{tabular}{|ll|l|l|l|l|l|}
\hline \multirow{2}{*}{ Model } & Unstandardized Coefficients & Standardized Coefficients & $t$ \\
\cline { 2 - 5 } & (Constant) & B & Std. Error & Beta & \\
\hline \multirow{2}{*}{$\begin{array}{l}\text { Sistem Administrasi Modern } \\
1\end{array}$} & 12.194 & 3.729 & & 3.270 & .001 \\
& Keadilan & .162 & .078 & .177 & 2.062 \\
& Akuntabilitas & .326 & .154 & .191 & .042 \\
& Sanksi Perpajakan & .347 & .148 & .212 & .037 \\
\end{tabular}

a. Dependent Variable: Kepatuhan Wajib Pajak

Sumber: Data Olahan Output IBM SPSS versi 21 (2020)

Pada tabel di atas, maka dapat dibuat persamaan regresi linear berganda sebagai berikut:

$\mathbf{Y}=12.194+0,162 \mathbf{X} \mathbf{1}+0,326 \mathbf{X} \mathbf{2}+0,329 \mathbf{X 3}+0,347 \mathbf{X} \mathbf{4}$

Interpretasinya:

a. Nilai Konstanta bernilai 12.194. nilai tersebut menyatakan bahwa variable independen (system administrasi 
modern, keadilan Akuntabilitas, Sanksi Perpajakan) dianggap konstan, maka variabel dependen (kepatuhan wajib pajak UMKM Kota jambi) adalah sebesar 12.194.

b. Koefisien variabel sistem administrasi modern (X1) bernilai positif sebesar 0,162. Hal ini menyatakan bahwa setiap kenaikan sistem administrasi modern sebesar 1, maka kepatuhan wajib pajak UMKM Kota jambi akan bertambah sebesar 0,162 dengan asumsi variabel lain bernilai tetap atau sama dengan nol.

c. Koefisien variabel keadilan (X2) bernilai positif sebesar 0,326. Hal ini menyatakan bahwa setiap kenaikan keadilan sebesar 1, maka kepatuhan wajib pajak UMKM Kota jambi akan meningkat sebesar 0,326 dengan asumsi variabel lain bernilai tetap atau sama dengan nol.

d. Koefisien variabel akuntabilitas (X3) bernilai positif sebesar 0,329. Hal ini menyatakan bahwa setiap kenaikan akuntabilitas sebesar 1, maka kepatuhan wajib pajak UMKM Kota jambi akan menurun sebesar 0,329 dengan asumsi variabel lain bernilai tetap atau sama dengan nol.

e. Koefisien variabel sanksi perpajakan (X4) bernilai positif sebesar 0,347. Hal ini menyatakan bahwa setiap kenaikan sanksi perpajakan sebesar 1, maka kepatuhan wajib pajak UMKM Kota jambi akan bertambah sebesar 0,347 dengan asumsi variabel lain bernilai tetap atau sama dengan nol.

\section{Uji Hipotesis \\ Uji Statistik $\boldsymbol{F}$}

Uji statistik F digunakan untuk menguji apakah persamaan regresi dalam penelitian ini dalam kondisi goodness of fit atau layak (fit) untuk diinterpretasikan Penelitian dikatakan memiliki model yang fit dengan data yang dimiliki apabaila nilai probabilitas signifikansi $<0,05$ diukur dengan uji ANOVA (Ghozali, 2018). Berikut data yang telah diolah untuk uji F seperti di bawah ini:

Tabel 8

Hasil Uji Statistik F

\begin{tabular}{|c|c|c|c|c|c|c|}
\hline \multicolumn{7}{|c|}{ ANOVAa } \\
\hline & Model & Sum of Squares & Df & Mean Square & $\mathrm{F}$ & Sig. \\
\hline \multirow{3}{*}{1} & Regression & 791.503 & 4 & 197.876 & 12.866 & $.000^{\mathrm{b}}$ \\
\hline & Residual & 1461.087 & 95 & 15.380 & & \\
\hline & Total & 2252.590 & 99 & & & \\
\hline
\end{tabular}

Sumber: Data Olahan Output IBM SPSS versi 21 (2020)

Berdasarkan hasil tabel di atas, maka dapat dilihat bahwa nilai signifikansi 0,000. Nilai probabilitas signifikansi lebih kecil dari 0,05 , maka dapat disimpulkan bahwa model dalam penelitian ini layak dan dapat digunakan untuk memprediksi variabel kepatuhan wajib pajak UMKM Kota jambi.

\section{Uji Koefisien Determinasi (R2)}

Koefisien determinasi dinyatakan dengan $R^{2}$, pada intinya digunakan $R^{2}$ untuk mengukur seberapa jauh kemampuan model dalam menerangkan variasi variabel independen. Nilai koefisien determinasi berada antara 0 dan 1. Nilai $R^{2}$ yang mendekati 1 memberi arti bahwa variabel-variabel independen memberikan seluruh informasi yang dibutuhkan untuk memprediksi variabel dependen (Ghozali, 2018). Uji ini dilakukkan untuk mengukur seberapa peranan variabel sistem administrasi modern, keadilan, akuntabilitas, sanksi perpajakan dapat menjelaskan variabel dependen, yaitu kepatuhan wajib pajak UMKM Kota jambi. Hasil uji koefisien determinasi dapat dilihat dari kolom Adjusted R Square yang ditampilkan pada tabel berikut:

Tabel 9

Hasil Uji Determinant

\begin{tabular}{|c|c|c|c|c|}
\hline \multicolumn{4}{|c|}{ Model Summary } \\
\hline Model & \multicolumn{1}{|c|}{ R } & \multicolumn{1}{c|}{ R Square } & Adjusted R Square & Std. Error of the Estimate \\
\hline 1 & $.593^{\text {a }}$ & .351 & .324 & 3.922 \\
\hline a. Predictors: (Constant), Sanksi Perpajakan, Sistem Administrasi Modern, Keadilan, Akuntabilitas \\
\hline
\end{tabular}

Sumber: Data Olahan Output IBM SPSS versi 21 (2020)

Tabel 9 menunjukan bahwa nilai Adjusted R Square sebesar 0,324 atau 32,4\%. Hal ini berarti bahwa kontribusi variabel independen yaitu sistem administrasi modern, keadilan, akuntabilitas, sanksi perpajakan terhadap variabel dependen yaitu kepatuhan wajib pajak UMKM Kota jambi sebesar 32,4\%, sedangkan sisanya 67,6\% dijelaskan oleh variabel lain diluar independen yang digunakan. 
Eva Setiarini Damanik, Pengaruh Sistem Administrasi Modern, Keadilan, Akuntabilitas, Dan Sanksi Perpajakan terhadap Kepatuhan Wajib Pajak UMKM Kota Jambi

\section{Uji Statistik $t$}

Uji statistik t digunakan untuk menguji pengaruh dari masing-masing variabel independen secara parsial terhadap variabel dependen. Untuk mengetahui ada tidaknya pengaruh masing-masing variabel independen secara parsial terhadap variabel dependen dapat dilihat pada tingkat signifikansi 0,05 . Hasil uji statistik $t$ dapat dilihat pada tabel. Jika nilai sig. < 0,05 maka hipotesis didukung, sedangkan jika nilai sig. > 0,05 maka hipotesis tidak didukung (Ghozali, 2018). Berikut ini hasil dari uji statistik t:

Tabel 10

Hasil Uji Statistik t

\begin{tabular}{|c|c|c|c|c|c|c|}
\hline \multicolumn{7}{|c|}{ Coefficientsa } \\
\hline \multirow{2}{*}{\multicolumn{2}{|c|}{ Model }} & \multicolumn{2}{|c|}{ Unstandardized Coefficients } & \multirow{2}{*}{\begin{tabular}{|l} 
Standardized Coefficients \\
Beta
\end{tabular}} & \multirow[t]{2}{*}{$\mathrm{t}$} & \multirow[t]{2}{*}{ Sig. } \\
\hline & & $\mathrm{B}$ & Std. Error & & & \\
\hline \multirow{5}{*}{1} & (Constant) & 12.194 & 3.729 & & 3.270 & .001 \\
\hline & Sistem Administrasi Modern & .162 & .078 & .177 & 2.062 & .042 \\
\hline & Keadilan & .326 & .154 & .191 & 2.113 & .037 \\
\hline & Akuntabilitas & .329 & .148 & .212 & 2.226 & .028 \\
\hline & Sanksi Perpajakan & .347 & .106 & .295 & 3.274 & .001 \\
\hline
\end{tabular}

Sumber: Data Olahan Output IBM SPSS versi 21 (2020)

\section{Hasil Uji Hipotesis 1}

Variabel sistem administrasi modern memiliki nilai signifikansi sebesar 0,042 atau lebih kecil dari 0,05. Hal tersebut dapat dikatakan bahwa hipotesis pertama diterima, sehingga dapat dikatakan bahwa sistem administrasi modern berpengaruh terhadap kepatuhan wajib pajak UMKM Kota jambi.

\section{Hasil Uji Hipotesis 2}

Variabel keadilan memiliki nilai signifikansi sebesar 0,037 atau lebih kecil dari 0,05. Hal tersebut dapat dikatakan bahwa hipotesis kedua diterima, sehingga dapat dikatakan bahwa keadilan berpengaruh terhadap kepatuhan wajib pajak UMKM Kota jambi.

\section{Hasil Uji Hipotesis 3}

Variabel akuntabilitas memiliki nilai signifikansi sebesar 0,028 atau lebih kecil dari 0,05. Hal tersebut dapat dikatakan bahwa hipotesis ketiga diterima, sehingga dapat dikatakan bahwa akuntabilitas berpengaruh terhadap kepatuhan wajib pajak UMKM Kota jambi.

\section{Hasil Uji Hipotesis 4}

Variabel sanksi perpajakan memiliki nilai signifikansi sebesar 0,001 atau lebih kecil dari 0,05. Hal tersebut dapat dikatakan bahwa hipotesis keempat diterima, sehingga dapat dikatakan bahwa sanksi perpajakan berpengaruh terhadap kepatuhan wajib pajak UMKM Kota jambi.

\section{Pembahasan \\ Pengaruh Sistem Administrasi Modern terhadap Kepatuhan Wajib Pajak UMKM Kota jambi}

Berdasarkan hasil analisis statistik dalam penelitian ini menunjukkan bahwa variabel sistem administrasi modern berpengaruh terhadap variabel kepatuhan wajib pajak UMKM Kota jambi. Hal ini ditunjukkan dengan besarnya nilai siginifikansi yaitu 0,042 atau lebih kecil dari taraf signifikansi 0,05 . Sehingga dapat disimpulkanbahwa hipotesis pertama $\left(\mathrm{H}_{1}\right)$ dalam penelitian ini diterima, sehingga sistem administrasi modern berpengaruh terhadap kepatuhan wajib pajak UMKM Kota jambi. Semakin banyak wajib pajak yang memahami mengenai kemudahan sistem administrasi modern dan semakin baik sistemnya maka akan meningkatkan kepatuhan wajib pajak UMKM Kota jambi.

Berdasarkan hasil yang diperoleh, menunjukkan bahwa pemahaman Wajib Pajak UMKM Kota jambi mengenai kemudahan sistem administrasi modern sudah baik, yang berarti Wajib Pajak UMKM Kota jambi sudah memahami manfaat dan kemudahan sistem administrasi modern tersebut. Serta jika target penerimaan pemerintah terpenuhi berarti sistem administrasi modern sudah baik.

Hasil penelitian ini sesuai dengan penelitian Putri, dkk (2019), Aryati dan Putritanti (2016), Prabawati (2017), Sarunan (2015) yang menyatakan bahwa sistem administrasi modern berpengaruh terhadap kepatuhan wajib pajak UMKM. Namun bertolak belakang dengan penelitian yang dilakukan oleh Qodariyah, dkk (2018) dan Putra (2017) sistem administrasi modern tidak berpengaruh terhadap kepatuhan wajib pajak UMKM. 
Eva Setiarini Damanik, Pengaruh Sistem Administrasi Modern, Keadilan, Akuntabilitas, Dan Sanksi Perpajakan terhadap Kepatuhan Wajib Pajak UMKM Kota Jambi

\section{Pengaruh Keadilan terhadap Kepatuhan Wajib Pajak UMKM Kota jambi}

Berdasarkan hasil analisis statistik dalam penelitian ini menunjukkan bahwa variabel keadilan berpengaruh terhadap variabel kepatuhan wajib pajak UMKM Kota jambi. Hal ini ditunjukkan dengan besarnya nilai siginifikansi yaitu 0,037 atau lebih kecil dari taraf signifikansi 0,05. Sehingga dapat disimpulkan bahwa hipotesis kedua $\left(\mathrm{H}_{2}\right)$ dalam penelitian ini diterima, sehingga keadilan berpengaruh terhadap kepatuhan wajib pajak UMKM Kota jambi. Semakin banyak wajib pajak yang memahami mengenai keadilan perpajakan maka akan meningkatkan kepatuhan wajib pajak UMKM Kota jambi.

Berdasarkan hasil yang diperoleh, menunjukkan bahwa pemahaman Wajib Pajak UMKM Kota jambi mengenai keadilan sudah baik, yang berarti Wajib Pajak UMKM Kota jambi sudah merasakan adanya keadilan perpajakan yang sesuai dengan undang-undang yang ditetapkan. Masalah keadilan sudah ditanggapi pemerintah dengan baik, dan UMKM merasa diperlakukan dengan adil karena UMKM yang menyusun laporan keuangan dikenakan pajak berdasarkan tarif $0,5 \%$, dan yang tidak menyusun laporan dikenakan pajak berdasarkan omsetnya. Namun, dalam hal ini pemerintah tetap harus mengantisipasi masalah yang sangat mendasar yang selalu dijumpai dalam pemungutan dan pengalokasian dana pajak supaya keadilan pajak selalu terwujud.

Hasil penelitian ini sesuai dengan penelitian Mustofa, dkk (2016), yang menyatakan bahwa keadilan berpengaruh terhadap kepatuhan wajib pajak UMKM. Namun bertolak belakang dengan penelitian yang dilakukan oleh Raihan (2018) dan Averti dan Rossje (2018) yang menyatakan bahwa keadilan berpengaruh terhadap kepatuhan wajib pajak UMKM.

\section{Pengaruh Akuntabilitas terhadap Kepatuhan Wajib Pajak UMKM Kota jambi}

Berdasarkan hasil analisis statistik dalam penelitian ini menunjukkan bahwa variabel akuntabilitas berpengaruh terhadap variabel kepatuhan wajib pajak UMKM Kota jambi. Hal ini ditunjukkan dengan besarnya nilai siginifikansi yaitu 0,028 atau lebih kecil dari taraf signifikansi 0,05 . Sehingga dapat disimpulkan bahwa hipotesis ketiga $\left(\mathrm{H}_{3}\right)$ dalam penelitian ini diterima, sehingga akuntabilitas berpengaruh terhadap kepatuhan wajib pajak UMKM Kota jambi. Semakin banyak wajib pajak yang memahami mengenai akuntabilitas maka akan meningkatkan kepatuhan wajib pajak UMKM Kota jambi.

Berdasarkan hasil yang diperoleh, menunjukkan bahwa pemahaman Wajib Pajak UMKM Kota jambi mengenai akuntabilitas sudah baik, yang berarti Wajib Pajak UMKM Kota jambi sudah percaya akan kinerja pemerintah dalam hal ini tentang pengalokasian dari hasil perpajakan. Akuntabilitas yang dilakukan pemerintah sudah baik dilihat dari kepercayaan yang diberikan masyarakat terhadap pemerintah.

Hasil penelitian ini sesuai dengan penelitian Putri, dkk (2019) dan Broto (2018) yang menyatakan bahwa akuntabilitas berpengaruh terhadap kepatuhan wajib pajak UMKM. Namun bertolak belakang dengan penelitian yang dilakukan oleh Lilisen, dkk., (2018) yang menyatakan bahwa akuntabilitas tidak berpengaruh terhadap kepatuhan wajib pajak UMKM.

\section{Pengaruh Sanksi Perpajakan terhadap Kepatuhan Wajib Pajak UMKM Kota jambi}

Berdasarkan hasil analisis statistik dalam penelitian ini menunjukkan bahwa variabel sanksi perpajakan berpengaruh terhadap variabel kepatuhan wajib pajak UMKM Kota jambi. Hal ini ditunjukkan dengan besarnya nilai siginifikansi yaitu 0,001 atau lebih kecil dari taraf signifikansi 0,05. Sehingga dapat disimpulkan bahwa hipotesis keempat $\left(\mathrm{H}_{4}\right)$ dalam penelitian ini diterima, sehingga sanksi perpajakan berpengaruh terhadap kepatuhan wajib pajak UMKM Kota jambi. Semakin tegas sanksi yang diberikan, maka semakin meningkat kepatuhan wajib pajak UMKM Kota jambi.

Berdasarkan hasil yang diperoleh, menunjukkan bahwa dengan adanya ketegasan sanksi perpajakan, para pelaku UMKM Kota jambi sudah mematuhi peraturan perpajakan yang telah ditetapkan. Dengan alasan para pelaku UMKM Kota jambi menyadari peraturan dan sanksi yang diterima baik sanksi administrasi maupun pidana yang akan diterima apabila tidak memenuhi kewajiban perpajakannya, maka dengan adanya sanksi yang tegas menunjukkan kepatuhan pajak pelaku UMKM Kota jambi akan semakin meningkat dan menunjukkan bahwa sanksi perpajakan yang dibuat pemerintah sudah baik.

Hasil penelitian ini sesuai dengan penelitian Putri, dkk., (2019), Ngadiman dan Huslin (2015) yang menyatakan bahwa sanksi perpajakan berpengaruh terhadap kepatuhan wajib pajak UMKM. Namun bertolak belakang dengan penelitian yang dilakukan oleh Ermawati \& Afifi (2018) yang menyatakan bahwa sanksi perpajakan tidak berpenaruh terhadap kepatuhan wajib pajak UMKM.

\section{SIMPULAN}

Berdasarkan hasil analisis data dan pembahasan tentang perngaruh sistem administrasi modern, keadilan, akuntabilitas, sanksi perpajakan terhadap kepatuhan wajib pajak UMKM Kota jambi maka dapat diambil beberapa kesimpulan sebagai berikut: 
Eva Setiarini Damanik, Pengaruh Sistem Administrasi Modern, Keadilan, Akuntabilitas, Dan Sanksi Perpajakan terhadap Kepatuhan Wajib Pajak UMKM Kota Jambi

1. Sistem administrasi modern berpengaruh terhadap kepatuhan wajib pajak UMKM Kota jambi. Hal ini berarti semakin baik sistem administrasi modern yang dibuat oleh pemerintah, maka akan meningkatkan kepatuhan wajib pajak UMKM Kota jambi.

2. Keadilan berpengaruh terhadap kepatuhan wajib pajak UMKM Kota jambi.Hal ini berarti semakin baik keadilan yang diberikan oleh pemerintah, maka akan meningkatkan kepatuhan wajib pajak UMKM Kota jambi.

3. Akuntabilitas berpengaruh terhadap kepatuhan wajib pajak UMKM Kota jambi. Hal ini berarti semakin baik akuntabilitas yang dimiliki oleh pemerintah, maka akan meningkatkan kepatuhan wajib pajak UMKM Kota jambi.

4. Sanksi perpajakan berpengaruh terhadap kepatuhan wajib pajak UMKM Kota jambi. Hal ini berarti semakin baik sanksi perpajakan yang dibuat oleh pemerintah, maka akan meningkatkan kepatuhan wajib pajak UMKM Kota jambi.

\section{DAFTAR PUSTAKA}

Anwar, Darari Raihan. 2018. Pengaruh Norma Subjektif, Keadilan Perpajakan, Religiusitas, Dan Self Efficacy Terhadap Kepatuhan Wajib Pajak Orang Pribadi. Skripsi. Universitas Islam Indonesia, Yogyakarta.

Aryati, T., \& Putritanti, L. R. (2016). Pengaruh Pemanfaatan Teknologi dan Modernisasi Sistem Administrasi Perpajakan Terhadap Kepatuhan Wajib Pajak Orang Pribadi. Jurnal Riset Akuntansi dan Keuangan, 4(3). 11551168. Program studi Akuntansi, Fakultas Ekonomi, Universitas Trisakti.

Averti, Ancilla Regina., \& Rossje Vitarimetawatty Suryaputri. 2018. Pengaruh Keadilan Perpajakan, Sistem Perpajakan, Diskriminasi Perpajakan, Kepatuhan Wajib Pajak Terhadap Penggelapan Pajak. Jurnal Akuntansi Trisakti. Volume. 5 Nomor. 1. Fakultas Ekonomi Dan Bisnis Universitas Trisakti.

Bppk.kemenkeu.go.id. (2017, 13 Juli). "Indikator Keberhasilan DJP adalah Tingkat Kepatuhan Wajib Pajak". Diperoleh 05 Oktober 2019. https://bppk.kemenkeu.go.id/id/berita-pajak/24086-indikatorkeberhasilan-djp- adalWah-tingkat-kepatuhan-wajib-pajak.

Broto, S. S. 2018. Apakah Akuntabilitas Pemerintah dan Reformasi Administrasi Perpajakan Mempengaruhi Kepatuhan Wajib Pajak di Indonesia? Jurnal Widyaiswara Nasional 1,1(2), 76-92.

Danarsi, Siti Nurlela, Hendro Subroto. 2017. Faktor-faktor yang Mempengaruhi Kepatuhan Wajib Pajak dalam Membayar Pajak Mobil dengan Diberlakukannya Pajak Progresif di Kota Surakarta. Jurnal Akuntansi dan Pajak. Volume. 18. No. Universitas Islam Batik, Surakarta.

Ermawati, Nanik dan Zaenal Afifi. 2018. Pengaruh Pengetahuan Perpajakan Dan Sanksi Perpajakan Terhadap Kepatuhan Wajib Pajak Dengan Religiusitas Sebagai Variabel Pemoderasi. Program Studi Akuntansi, Fakultas Ekonomi dan Bisnis, Universitas Muria Kudus.

Ghozali, Imam. 2018. Aplikasi Analisis Multivariate dengan Program IBM SPSS25. Semarang: Badan Penerbit Universitas Diponegoro.

Keputusan Menteri Keuangan No. 544/KMK.04/2000 Tentang Kepatuhan Wajib Pajak. Krjogja.com (2018, 10 September). Kesadaran Pajak UMKM di DIY Masih Rendah. Diperoleh $11 \quad$ Oktober 2019. https://www.krjogja.com/berita-lokal/diy/yogyakarta/kesadaran-pajak-umkm-di-diy-masih-rendah/

Lilisen, Ratnawati, V., \& Indrawati, N. 2018. The Effect of The Taxation System, Accountability and Examination Risk to The Taxpayer Compliance with Taxpayer Morale As A Moderating Variable. PEKBIS (Jurnal Pendidikan Ekonomi Dan Bisnis), 10(2), 103-117.

Mardiasmo. 2016. Perpajakan. Edisi Terbaru. Yogyakarta: Andi.

Mustofa, Fauzi Achmad., Kertahadi dan Mirza M. R. 2016. Pengaruh Pemahaman Peraturan Perpajakan, Tarif Pajak dan Asas Keadilan Terhadap Kepatuhan Wajib Pajak. Jurnal Perpajakan (JEJAK). 8(1): 1-7. Jurusan Administrasi Bisnis, Fakutas Ilmu Administrasi, Universitas Brawijaya.

Ngadiman, \& Huslin, D. 2015. Pengaruh Sunset Policy, Tax Amnesty, dan Sanksi Pajak terhadap Kepatuhan Wajib Pajak (Studi Empiris di Kantor Pelayanan Pajak Pratama Jakarta Kembangan). Jurnal Akuntansi, XIX(02), 225241. Fakultas Ekonomi Universitas Tarumanagara.

Pandiangan, Roristua. 2015. Hukum Pajak. Yogyakarta: Graha Ilmu.

Prabawati, Y. T. 2017. Pengaruh Modernisasi Sistem Administrasi Perpajakan, Kualitas Pelayanan, dan Presepsi Wajib Pajak Atas Sanksi Pajak Terhadap Kepatuhan Wajib Pajak. STIE Perbanas Surabaya, 1-20.

Putra, A. F. 2017. Pengaruh Etika, Sanksi Pajak, Modernisasi Sistem, Dan Transparansi Pajak Terhadap Kepatuhan Pajak. Jurnal Akuntansi Indonesia, Vol. 6 No. 1. Fakultas Ekonomi Universitas Islam Indonesia, Yogyakarta.

Putri, N,P., Tanno, A,. Kurniawan, R. 2019. Pengaruh Sistem Administrasi Perpajakan Modern, Akuntabilitas Dan Sanksi Perpajakan Terhadap Kepatuhan Wajib Pajak. Jurnal Benefita 4(2) Juli 2019 (386-398). Fakultas Ekonomi Universitas Andalas, Padang, Indonesia.

Qodariyah, I., Suryadi, D., dan Yuniati. (2018). Pengaruh Modernisasi Sistem Administrasi Perpajakan Dan Penyuluhan Perpajakan Terhadap Kepatuhan Wajib Pajak Badan. Jurnal Ilmiah MEA (Manajemen, Ekonomi, \& Akuntansi), 2(3), 84-108. LPPM STIE Muhammadiyah Bandung. 
Eva Setiarini Damanik, Pengaruh Sistem Administrasi Modern, Keadilan, Akuntabilitas, Dan Sanksi Perpajakan terhadap Kepatuhan Wajib Pajak UMKM Kota Jambi

Rahayu, N. 2017. Pengaruh Pengetahuan Perpajakan, Ketegasan Sanksi Pajak, dan Tax Amnesty Terhadap Kepatuhan Wajib Pajak. Akuntansi Dewantara Vol.1 No.1. Fakultas Ekonomi Universitas Sarjanawiyata Taman Siswa.

Sarunan, W. K. 2015. Pengaruh Modernisasi Sistem Administrasi Perpajakan Terhadap Kepatuhan Wajib Pajak Orang Pribadi dan Wajib Pajak Badan Pada Kantor Pelayanan Pajak Pratama Manado. Jurnal EMBA, 3(4), 518-55526

Sekaran, Uma \& Bougie, Roger. 2017. Research Method for Business A Skill Building Approach (6 ${ }^{\text {th }}$ Edition). United Kingdom: John Wiley \& Sons.

Subekti, S.A. 2016. Faktor-Faktor yang Berpengaruh terhadap Kepatuhan Wajib Pajak dengan Preferensi Risiko sebagai Variabel Pemoderasi (Studi Kasus pada Wajib Pajak Badan Hotel Di DIY). Naskah Publikasi. Program Studi Akuntansi, Fakultas Ekonomi dan Bisnis, Universitas Muhammadiyah Yogyakarta.

Sufiah dan Lintang Venusita. 2017. Pengaruh Faktor Internal dan Faktor Eksternal pada Kepatuhan Wajib Pajak Orang Pribadi Di Kota Surabaya. Jurusan Akuntansi Fakultas Ekonomi Universitasi Negeri Surabaya.

Sugiyono. (2016). Metode Penelitian Kuantitatif, Kualitatif dan R\&D. Bandung: PT Alfabet.

Tatik. (2018). Potensi Kepatuhan Pembayaran Pajak Pada Pelaku UMKM (Usaha Mikro Kecil dan Menengah) Pasca Penerbitan Peraturan Pemerintah No. 23 Tahun 2018 (Studi Kasus Pada UMKM di Kabupaten SlemanYogyakarta).Seminar Nasional dan Call for Paper Sustainble Competitive Advantage (SCA)

Undang-Undang No. 16 Tahun 2009 pasal 1 ayat 1 Tentang Ketentuan Umum

Undang-Undang No. 16 Tahun 2009 tentang Perubahan Ketiga atas Undang-Undang No. 6 Tahun 1983 tentang ketentuan Perpajakan.

Undang-Undang No. 16 Tahun 2009 tentang Perubahan Ketiga atas Undang-Undang No. 6 Tahun 1983 tentang ketentuan Perpajakan

Undang-Undang Nomor 20 Tahun 2008 tentang Usaha Mikro, Kecil dan Menengah (UMKM) 